\title{
Neuroprotective Effect of Memantine on Hippocampal Neurons in Infantile Rat Hydrocephalus
}

\section{Infant Sıçanda Oluşturulan Hidrosefalide Memantin Uygulanmasının Hipokampal Nöronlar Üzerindeki Koruyucu Etkisi}

\author{
Burak CABUK ${ }^{1}$, Volkan ETUS ${ }^{2}$, Suheyla UYAR BOZKURT ${ }^{3}$, Aydin $\mathrm{SAV}^{4}$, Savas CEYLAN ${ }^{2}$ \\ ${ }^{1}$ Turkish Navy Golcuk Military Hospital, Department of Neurosurgery, Kocaeli, Turkey \\ ${ }^{2}$ Kocaeli University, Faculty of Medicine, Department of Neurosurgery, Kocaeli, Turkey \\ ${ }^{3}$ Marmara University, Faculty of Medicine, Department of Pathology, Istanbul, Turkey \\ ${ }^{4}$ Acibadem University, Faculty of Medicine, Department of Pathology, Istanbul, Turkey
}

Correspondence address: Volkan ETUS / E-mail: drvolkanetus@yahoo.com

\begin{abstract}
AIM:The effect of memantine administration on hippocampal neurons of the infantile rats with kaolin induced hydrocephalus was investigated. MATERIAL and METHODS: Hydrocephalus was induced by injecting kaolin into the cisterna magna of 3-weeks old Sprague-Dawley rat pups. One group received a single daily dose of $20 \mathrm{mg} / \mathrm{kg}$ memantine i.p. following hydrocephalus induction for a period of two weeks. By the end of the two-week period, animals were radiologically evaluated by magnetic resonance imaging and then sacrificed to get their cerebrums removed. Both immunohistochemical analysis of nitric oxide synthase activity and quantification of spared neurons in CA1, CA2 and CA3 regions of hippocampus were performed.

RESULTS: In hydrocephalus-induced rats considerable neuronal loss associated with significantly increased nitric oxide synthase immunoreactivity were determined in all hippocampal regions. However, memantine treated rats showed significantly higher number of spared neuron counts and reduced nitric oxide synthase immunoreactivity in CA1 and CA2 regions compared with the non-treated rats.

CONCLUSION:The findings of the study show that hippocampal neurons may constitute important targets for injury secondary to hydrocephalic process in experimental infantile hydrocephalus. Early anti-excitotoxic treatment with memantine seems to have a neuroprotective effect especially in the CA1 and CA2 subunits of the hippocampus.
\end{abstract}

KEYWORDS: Hippocampus, Hydrocephalus, Memantine, Neuroprotection, Rat

öz

AMAÇ: Infant sıçanda kaolin ile oluşturulan hidrosefali modelinde memantin tedavisinin hipokampal nöronlar üzerindeki etkisi araştırılmıştır. YÖNTEM ve GEREÇ: Üç haftalık Sprague-Dawley türü sıçan yavrularında sisterna magna içerisine kaolin süspansiyonu enjeksiyonu ile hidrosefali oluşturulmuştur. Hidrosefali indüksiyonunu takiben bir grup deneğe iki hafta süreyle günlük $20 \mathrm{mg} / \mathrm{kg}$ dozunda intraperitoneal yolla memantin verilmiştir. İki haftalık sürenin bitiminde tüm denekler manyetik rezonans görüntüleme ile incelendikten sonra sakrifiye edilerek serebrumları çıkartılmış ve hipokampus CA1, CA2 ve CA3 bölgelerinde sağlam nöron sayımı ile birlikte nöronal nitrik oksit sentaz aktivitesinin immünhistokimyasal analizi yapılmıştır.

BULGULAR: Hidrosefali oluşturulan gruplarda tüm hipokampal bölgelerde anlamlı nitrik oksit sentaz immünoreaktivitesi artışı ile birlikte nöron sayısında farkedilir azalma gözlenmiştir. Ancak memantin uygulanan deneklerin CA1 ve CA2 bölgelerinde nöron sayılarındaki azalmanın ve nitrik oksit sentaz immünoreaktivitesi artışın anlamlı düzeyde daha az olduğu saptanmıştır.

SONUÇ: Bu deneysel infantil hidrosefali çalışmasının sonuçları, hipokampal nöronların hidrosefalik sürece ikincil gelişen hasarlanma açısından önemli hedefler olduğunu göstermektedir. Memantin ile yapılan erken anti-eksitotoksik tedavinin özellikle hipokampus CA1 ve CA2 bölgeleri üzerinde nöron-koruyucu etki gösterdiği söylenebilir

ANAHTAR SÖZCÜKLER: Hidrosefali, Hipokampus, Memantin, Nöroproteksiyon, Sıçan 


\section{INTRODUCTION}

In the pathogenesis of hydrocephalus, besides the primary mechanical injury associated with ventricular dilatation, the presence of a mechanism of a secondary injury resulting from destructive and ischemic alterations in periventricular area was demonstrated both in experimentally-induced hydrocephalic animal models $(3,11,14)$ and in congenitally hydrocephalic rats (23). It has been observed that as long as the hydrocephalic process progresses, consequent alterations emerge preferably at those areas sensitive to ischemia. There are few studies comprehensively describing the injury mechanism in hippocampus during adult hydrocephalus $(6,8$, $16,25)$. Published data indicating the negative impacts of the hydrocephalic process on the hippocampus of the immature brain are even fewer in number (17). The hippocampus, especially its CA1 region, is known to be very susceptible to hypoxia and ischemia, and is a relatively important target for the secondary neuronal injury originated from hydrocephalic process. There are data regarding the neurodegenerative effect of hydrocephalic process especially on the pyramidal layer of CA1 subunit of hippocampus (15).

It is well known that secondary neuronal injury mechanisms can be impacted by pharmacological means in order to minimize secondary neuronal death following cerebral trauma and ischemia. The use of neuroprotective agents for preventing the secondary neuronal loss in the hydrocephalic process is a relatively a new issue and has not been studied widely. Regarding the neuroprotection in hydrocephalus, there are only a few reports published in the literature $(7,11$, 14).

In recent years, memantine, a non-competitive NMDA receptor antagonist, has been demonstrated to have protective effects on neuronal death due to transient frontal brain ischemia (2), hypoxic cerebral ischemia (4), spinal cord ischemia (9), neonatal cerebral focal ischemia (24) and retinal ischemia (21) in several animal models. It has also been shown to significantly decrease hippocampal neuronal cellular death that emerged one week after cerebral trauma in a cortical impact injury model (22).

In this study we investigated the potential neuroprotective effect of systemic memantine administration on hippocampal neurons in a rat model of newly onset childhood hydrocephalus. We hypothesized that during hydrocephalic process, memantine would have a protective effect on secondary neuronal injury in hippocampal neurons through its mechanism of preventing ischemia induced injury and neurotoxicity.

\section{MATERIAL and METHODS}

\section{Animals, hydrocephalus induction and verification}

Thirty Sprague-Dawley rat pups at age 3 weeks with a mean weight of $50 \pm 10$ grams were used in the study. The rats were provided by the Center of Reproduction of Animals for Experimental Studies of the University Medical School and the experiment was approved by the local Ethics Committee with the code number HAEK 20/2. All efforts were made to minimize suffering and the number of animals used. All surgical procedures were conducted and animals were cared for according to the Declaration of Helsinki. Rats were divided into 3 groups. Group 2 and Group 3 consisted of eleven rats and Group 1 (control group) consisted of eight rats. Anesthesia was induced in the rats by intramuscular injection of ketamine $(10 \mathrm{mg} / \mathrm{kg})$. Each rat's neck was shaved and a median cranio-cervical incision was done. Under binocular loupe magnification superficial and deep cervical muscles were separated off the midline and the atlanto-occipital membrane was identified. The membrane was penetrated at a right angle by a sterile insulin injector of $27 \mathrm{G}$ introduced into the cisterna magna. The cerebrospinal fluid outflow from the injection site was observed. Then $0.05 \mathrm{ml}$ of sterile kaolin (Kaolin hydrated Aluminum Silicate, Sigma Chemical Co., St. Louis, MO, USA) suspension ( $250 \mathrm{mg} / \mathrm{ml}$ in $0.9 \%$ saline) was slowly injected into the cisterna magna of the rats in Group 2 and Group 3. The animals in Group 1 received a sham injection consisting of needle insertion only. Cervical muscles and skin were closed with separate sutures. Pups were housed in standard cages (four animals/cage) and provided with a normal 12-hour day/night lighting schedule with free access to water and pellet food. After 24 hours, a single daily dose of $20 \mathrm{mg} / \mathrm{kg}$ of memantine (Ebixa ${ }^{\circledR}$, Lundbeck Inc.) solution prepared with $0.9 \%$ saline was injected into the peritoneum of the rats in Group 3. The first and the second group were injected the same volume of $0.9 \%$ saline solution. Injections were made once daily for two weeks. At the end of the twoweek period, radiological verification of the hydrocephalic process was done. Magnetic resonance imaging (MRI) was performed with a 1.5 Tesla MR device (Philips Intera) via the use of C3 coil circular surface to obtain T2-weighted images of the brain in the coronal plane. The lateral ventricles and cerebrum were evaluated in the rostral cerebrum immediately anterior to the third ventricle to verify ventricular dilatation. Following MRI evaluation, the rats were decapitated and their brains were removed. All the brains were transected at the bulbomedullar junction and then sectioned sagittally midline into two hemispheres. After labeling, all specimens were sent for histological and immunohistochemical analyses in a single-blinded fashion.

\section{Histological analysis}

Each hemisphere was sectioned coronally $(10 \mu \mathrm{m}$ thick at an interval of $320 \mu \mathrm{m}$ ) and the sections were stained with Hematoxylin-Eosin. Average neuronal counts in the CA1, CA2 and $C A 3$ regions of hippocampal area were assesed under a light microscope (Olympus U-MDOB3). For each animal, average neuronal counts were obtained by counting four serial coronal sections at $X 400$. Only complete neuronal cells with a clearly defined cell body and nucleus were counted as described in a previous study (22).

\section{Immunohistochemical analysis}

Tissue sections were deparaffinized and wet through graded alcohol. Endogenous peroxidase activity was blocked by incubation in 3\% hydrogen peroxide for $20 \mathrm{~min}$. After rinsing 
with distilled water, the sections were blocked with 1:10 normal goat serum to minimize nonspecific background staining. After protein blockage, the sections were incubated with u-NOS antibody for 60 minutes. The sections were then incubated in biotinylated goat anti-polyvalent for 20 minutes, and then in streptavidin peroxidase for 20 minutes. The slides were washed in running tap water and counterstained with $\mathrm{HE}$ for 20 seconds. Sections were washed again in running tap water and incubated with Lithium carbonate. They were then washed in water and covered.

For Nitric Oxide Synthase (NOS) immunostaining, Nitric Oxide Synthase-Universal (u-NOS) antibody (Lab Vision -RB9261-R7) was used. Immunoreactivity of NOS in hippocampal regions was observed at $400 \mathrm{x}$ and was graded according to the five-stage staining score system as described elsewhere (13) as 0: No staining, 1: stain concentration under 25\%, 2: stain concentration between $25 \%-50 \%$, 3: stain concentration between $50 \%-75 \%$ 4: stain concentration over $75 \%$.

\section{Statistical analysis}

Statistical analysis was performed by using the computer software program SPSS for Windows (SPSS Inc.). Neuron count values of the groups were analyzed by analysis of variance (ANOVA) with post hoc Tukey test calculations for intergroup comparisons. Statistical comparisons for NOS activity were made using Pearson's chi-square test. All p-values less than 0.05 were considered to be statistically significant. The data of this study were expressed as a mean value \pm standard error of mean (SEM).

\section{RESULTS}

Three rat pups (two in Group 2 and one in Group 3) that had complications during the hydrocephalic induction procedure and/or failed to develop hydrocephalus were excluded from the experimental protocol. The remaining 27 animals were classified as follows: Group 1 (non-hydrocephalic sham operated rats): $n=8$, Group 2 (non-treated hydrocephalic rats): $\mathrm{n}=9$ and Group 3 (memantine treated hydrocephalic rats): $\mathrm{n}=10$.

\section{Radiological evaluation}

In MRI examinations, T2-weighted images of the brain in the coronal plane were obtained. The lateral ventricles and cerebrum were evaluated in the rostral cerebrum immediately anterior to the third ventricle to verify ventricular dilatation. MRI studies revealed that one rat from Group 2 and one from the Group 3 failed to develop ventricular dilatation and those subjects were excluded from the study. Figure 1 shows an example of MR image displaying ventricular dilatation two weeks after the hydrocephalus induction. Figure 2 displays the MR image of a rat from Group 1 having normal ventricular structure.

\section{Neuron counts}

For each group, average number of spared neuronal cells with a clearly defined cell body and nucleus in CA1, CA2 and CA3 regions of hippocampus was determined. Table I summarizes

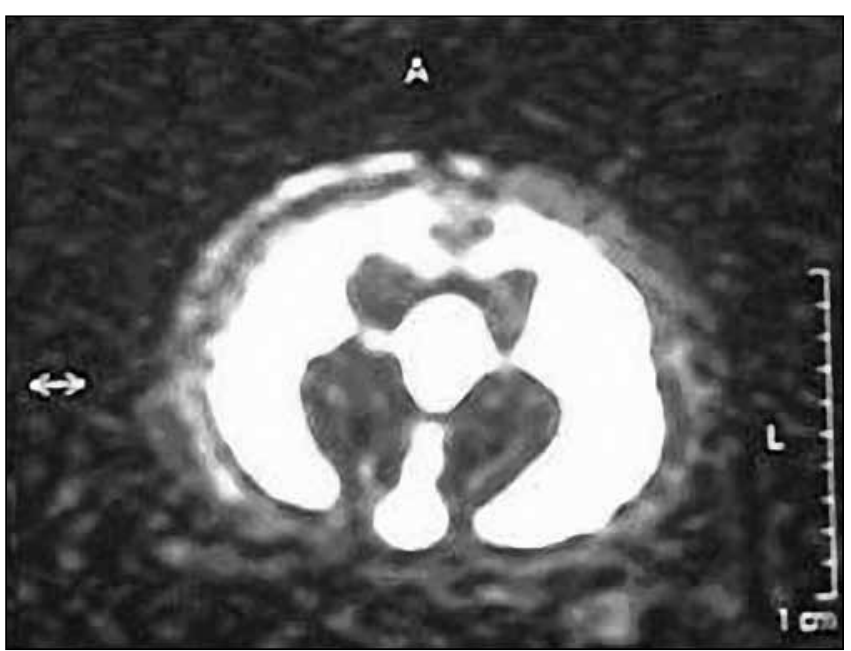

Figure 1: Magnetic resonance image (T2-weighted DRIVE coronal slice) through the rostral cerebrum of a hydrocephalus-induced rat. Severe ventricular enlargement is apparent.

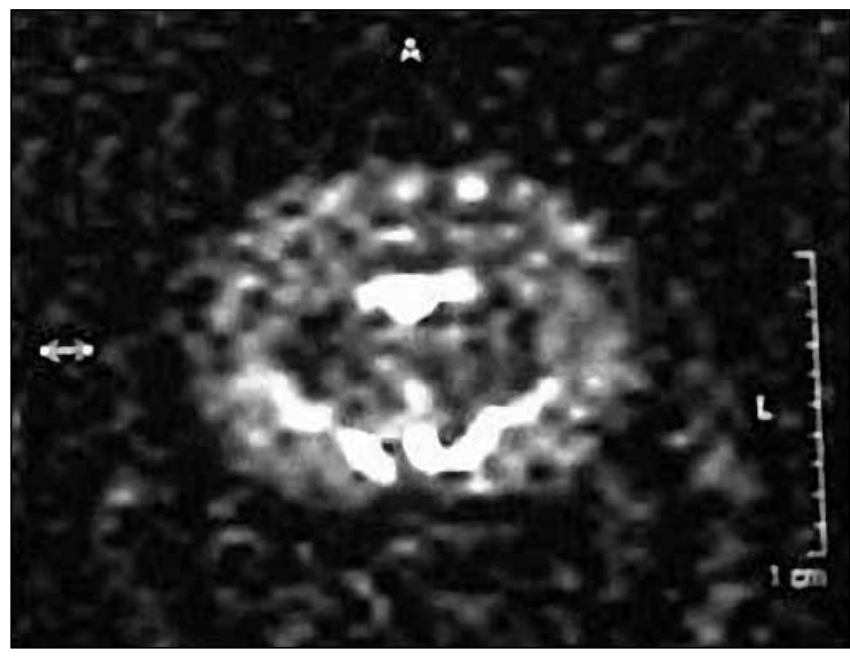

Figure 2: A, typical magnetic resonance image (T2-weighted DRIVE coronal slice) through the rostral cerebrum of a control rat revealing normal ventricular structure.

the data and the results of the statistical analyses done. Briefly, two weeks after the induction, the hydrocephalic process seemed to significantly decrease the average number of spared neurons in all regions of the hippocampus both in Group 2 and in Group 3. Memantine treated rat pups showed significantly higher number of spared neuron counts in $C A 1$ and $C A 2$ regions compared with the non-treated subjects. Figure 3 shows the localization of the CA1, CA2 and CA3 regions of hippocampus in the rat pup. Figure 4 shows an example of histological specimen revealing spared and degenerated neuronal structures in CA1 region.

\section{Nitric oxide synthase (NOS) immunoreactivity}

In each group, immunoreactivity of NOS in the CA1, CA2 and $\mathrm{CA} 3$ regions of the hippocampus was scored according to the 
five-stage grading system (13). Table II summarizes the data and the results of the statistical analyses performed. In short, our data showed that hydrocephalic process signifcantly increased the NOS immunoreactivity in CA1, CA2 and CA3 regions in Group 2 and in Group 3. The increase in NOS immunoreactivity was found to be significantly reduced in CA1 and $C A 2$ regions of the rats which had received memantine treatment during the hydrocephalic process compared with the non-treated rats. Figure 5 (I, II, III) shows examples of photomicrographs displaying immunoexpression of NOS for each group.

\section{DISCUSSION}

There are few studies comprehensively describing the injury mechanism in hippocampus during hydrocephalus $(6,8,16,17,25)$. It has been observed that as long as the hydrocephalic process progresses, consequent alterations emerge preferably at those areas sensitive to ischemia. There are data regarding especially the effect on the pyramidal layer of the CA1 subunit of the hippocampus (15). Decreased neurofilament and synaptophysin immunoreactivity in the hippocampus has been accepted as an indicator of neuronal degeneration in experimentally induced hydrocephalus (20).
In the hydrocephalic process, the decline of synaptophysin immunoreactivity in the hippocampus was suggested to remind the phenomenon of "delayed neuronal death", which is observed secondary to transient global ischemia $(15,19)$. In their study, Klinge et al. reported a global increase in NOS immunoreactivity in hippocampal neurons in kaolin-induced hydrocephalic adult rats two weeks after the induction. This increase was demonstrated to be in correlation with decreasing of cerebral blood flow at the early stage of hydrocephalus (16). They postulated that the global increase in hippocampal NOS staining of hydrocephalic subjects appeared to indicate a toxic neuronal response (16). Considering the important role of neuronal NOS enzyme in the acute excitotoxic injury of the central nervous system, an excitotoxic injury could be mentioned in the hydrocephalic process at hippocampus. In a previous study it has been well documented that neuronal NOS activation was secondary to an elevation of extracellular glutamate (10). The observations of Klinge et al. (16) seem to be in agreement with the findings of others (18) who found an increase in extracellular glutamate transporters in the short-term period after the induction of kaolin hydrocephalus. All these data show that the hydrocephalus process seem to affect hippocampal cells by the mechanism

Table I: Average Numbers of Spared Neuronal Cells with a Clearly Defined Cell Body and Nucleus in CA1, CA2 and CA3 Regions of Hippocampus for Each Group are Shown. The Data are Expressed as Mean Value \pm Standard Error of Mean. The Data were Analyzed by Analysis of Variance (ANOVA) with Post Hoc Tukey Test Calculations for Intergroup Comparisons

\begin{tabular}{|c|c|c|c|}
\hline & CA1 & CA2 & CA3 \\
\hline Group 1 & $105.75 \pm 1.74$ & $100.37 \pm 2.13$ & $94.50 \pm 1.36$ \\
\hline Group 2 & $79.13 \pm 1.21$ & $71.88 \pm 5.02$ & $69.61 \pm 3.15$ \\
\hline Group 3 & $88.43 \pm 1.41$ & $84.70 \pm 2.12$ & $73.10 \pm 3.33$ \\
\hline Group 1 - Group 2 & $p<0.05^{*}$ & $p<0.05^{*}$ & $p<0.05^{*}$ \\
\hline Group 2 - Group 3 & $p<0.05^{*}$ & $p<0.05^{*}$ & $p>0.05$ \\
\hline Group 1 - Group 3 & $p<0.05^{*}$ & $p<0.05^{*}$ & $p<0.05^{*}$ \\
\hline
\end{tabular}

*All $p$-values less than 0.05 were considered to be statistically significant.

Table II: For Each Group, Immunoreactivity of NOS in CA1, CA2 and CA3 Regions of Hippocampus was Scored According to Five-Stage Grading System (x)

\begin{tabular}{|c|c|c|c|c|c|c|c|c|c|c|c|c|c|c|c|}
\hline & \multicolumn{5}{|c|}{ CA1 } & \multicolumn{5}{|c|}{ CA2 } & \multicolumn{5}{|c|}{ CA3 } \\
\hline & 0 & 1 & 2 & 3 & 4 & 0 & 1 & 2 & 3 & 4 & 0 & 1 & 2 & 3 & 4 \\
\hline Group 1 & 6 & 2 & - & - & - & 6 & 2 & - & - & - & 7 & 1 & - & - & - \\
\hline Group 2 & - & 3 & 5 & 1 & - & - & - & 4 & 5 & - & - & 2 & 5 & 2 & - \\
\hline Group 3 & 4 & 5 & 1 & - & - & 1 & 6 & 1 & 2 & - & - & 6 & 4 & - & - \\
\hline Group 1 - Group 2 & \multicolumn{5}{|c|}{$p<0.05^{*}$} & \multicolumn{5}{|c|}{$p<0.05^{*}$} & \multicolumn{5}{|c|}{$p<0.05^{*}$} \\
\hline Group 2 - Group 3 & \multicolumn{5}{|c|}{$p<0.05^{*}$} & \multicolumn{5}{|c|}{$p<0.05^{*}$} & \multicolumn{5}{|c|}{$p>0.05$} \\
\hline Group 1 - Group 3 & \multicolumn{5}{|c|}{$p>0.05$} & \multicolumn{5}{|c|}{$p<0.05^{*}$} & \multicolumn{5}{|c|}{$p<0.05^{*}$} \\
\hline
\end{tabular}

0: No staining, 1: stain concentration under $25 \%$, 2: stain concentration between 25\%-50\% 3: stain concentration between 50\%-75\% 4: stain concentration over $75 \%$ Statistical analyze of the data was done using Pearson's chi-square test.

*All p-values less than 0.05 were considered to be statistically significant. 


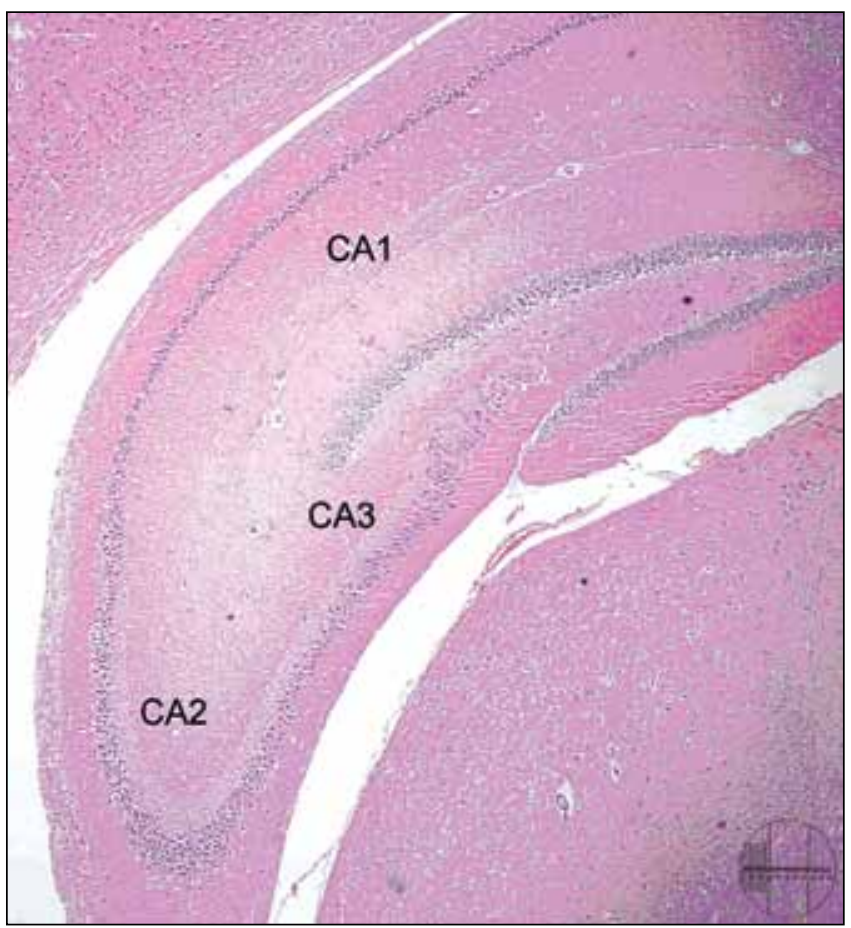

Figure 3: Hematoksilen-Eosine stained section showing CA1, CA2 and CA3 hippocampal regions under light microscope (X4 magnification, scale shows 100 microns).

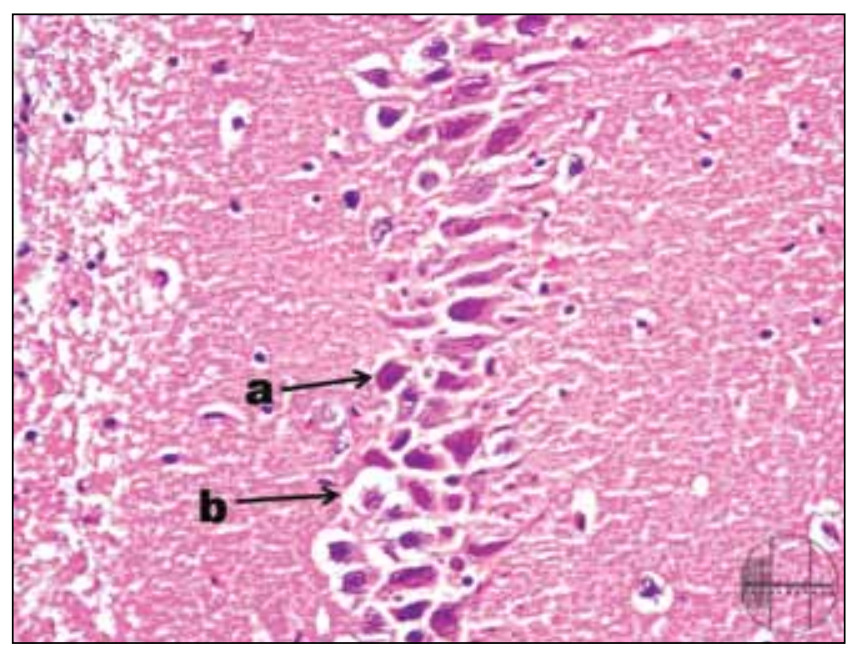

Figure 4: An example of Hematoksilen-Eosine stained section showing CA1 area of a hydrocephalus-induced rat (X400 magnification, scale shows 100 microns). a: Protected cell body and nucleus. b: Degenerating neuron.

of excitotoxic injury through elevation of extracellular glutamate due to decrease in cerebral blood flow. According to current knowledge, excitotoxicity has been shown to be an important component of pathogenesis of traumatic and ischemic injury of central nervous system. In addition, further evidence suggesting the role of excitotoxicity in many of the chronic neurological disorders, some where "anti-excitotoxic treatment" was considered to become a therapeutic choice, is increasing (11).

Memantine has been well demonstrated to have protective effects on secondary neuronal injury due to ischemia or trauma of the central nervous system $(4,5,9,21,22,24)$. Regarding its neuroprotective effects on hippocampus, memantine has been shown to significantly decrease hippocampal neuronal cellular death emerged one week after cortical impact injury model in the rat (22). Memantine, at $20 \mathrm{mg} / \mathrm{kg}$ of daily dose, was reported to exhibit a significant neuroprotective effect in experimental models where transient or permanent focal cerebral ischemia has been induced $(2,22)$.

The purpose of this study was to evaluate whether antiexcitotoxic treatment could protect or attenuate the adverse effects of hydrocephalic process on hippocampal neurons. To our best knowledge, this study is the first to evaluate effects of anti-excitotoxic treatment on the hippocampal neurons in a rat model of infantile hydrocephalus. Considering the proposed significant role of extracellular glutamate elevation in the excitotoxic injury of hippocampal cells in hydrocephalus process, we preferred memantine (a noncompetitive NMDA receptor antagonist) for anti-excitotoxic treatment in this study. Regarding the use of memantine in infantile hydrocephalus, there is only one study in the literature which, reported the effects of memantine treatment on esophageal and gastric smooth muscle reactivity (1). In that study, memantine treatment has been shown to influence the impaired contractile and relaxant activity of lower esophageal smooth muscle in hydrocephalus induced infantile rats (1). The present study is the first to report the effects of memantine treatment on hippocampal neurons in experimentally induced infantile hydrocephalus.

Our data showed that the average number of preserved neuronal cells with a clearly defined cell body and nucleus was significanly higher in CA1 and CA2 regions of the memantine treated hydrocephalic rat pups compared to non-treated hydrocephalic animals. In other words, daily administration of $20 \mathrm{mg} / \mathrm{kg}$ memantine when started in the early stages of the hydrocephalic process, significantly prevented neuronal degeneration in CA1 and CA2 subunits of the infantile rat hippocampus in radiologically verified hydrocephalus. These findings seem to be supported by the immunohistochemistry data of the study revealing that the increase in NOS immunoreactivity was significantly reduced in CA1 and CA2 regions of the rats that had received memantine treatment during the hydrocephalic process compared with the nontreated rats. The data of the present study, which revealed the significant increase of NOS immunoreactivity in CA1, CA2 and $C A 3$ regions of hippocampus in hydrocephalus induced rats, seem to be in agreement with the findings of Klinge et al. (16) who found a significant increase in hippocampal nitric oxide synthase activity two weeks after the induction of kaolin hydrocephalus. The increase in hippocampal NOS immunoreactivity, especially in the pyramidal layer of its CA1 subfield, is known to reflect the ischemia induced injury of the 

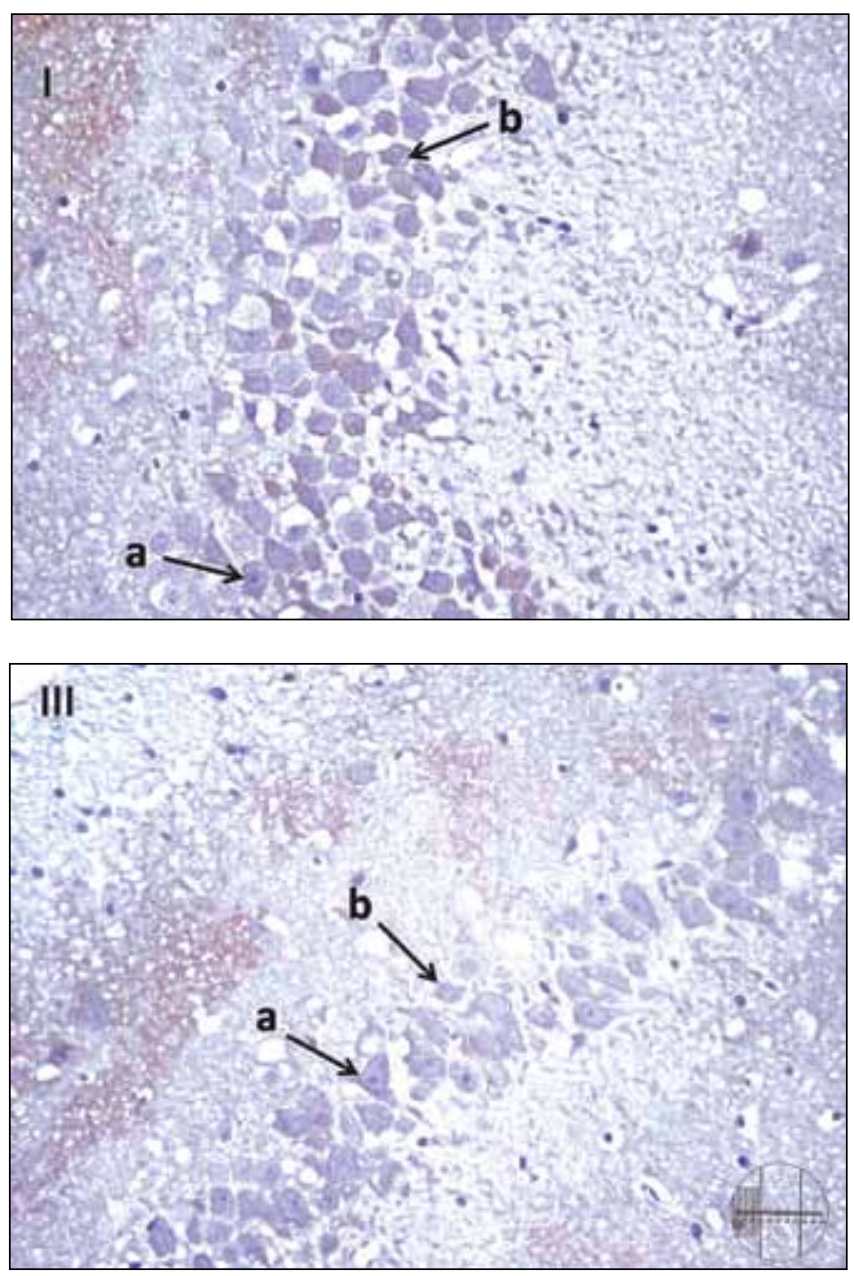

hippocampal neurons (15). In experimentally induced adult hydrocephalus, the increase in hippocampal NOS activity has been suggested to be induced by increased extracellular glutamate levels and to imply a toxic neuronal response (16). In our model of kaolin-induced infantile hydrocephalus, the data about the effectiveness of memantine treatment in reducing NOS immunoreactivity in $C A 1$ and $C A 2$ regions of the hippocampus, seem to support the hypothesis that hydrocephalic process may affect hippocampal cells by the mechanism of excitotoxic injury through elevation of extracellular glutamate. The present findings imply the possibility of that the protective effect of memantine on hippocampal neurons might be mediated by its glutamateNMDA receptor antagonism. A shortfall of the present study is the lack of cerebral blood flow measurements. Since simultaneous measurements of cerebral blood flow could not be performed, it was not possible to conclude whether or not this effect of memantine was mediated through any probable effect on cerebral blood flow. We are also far to interpret the data about the CA3 subunit of the hippocampus which

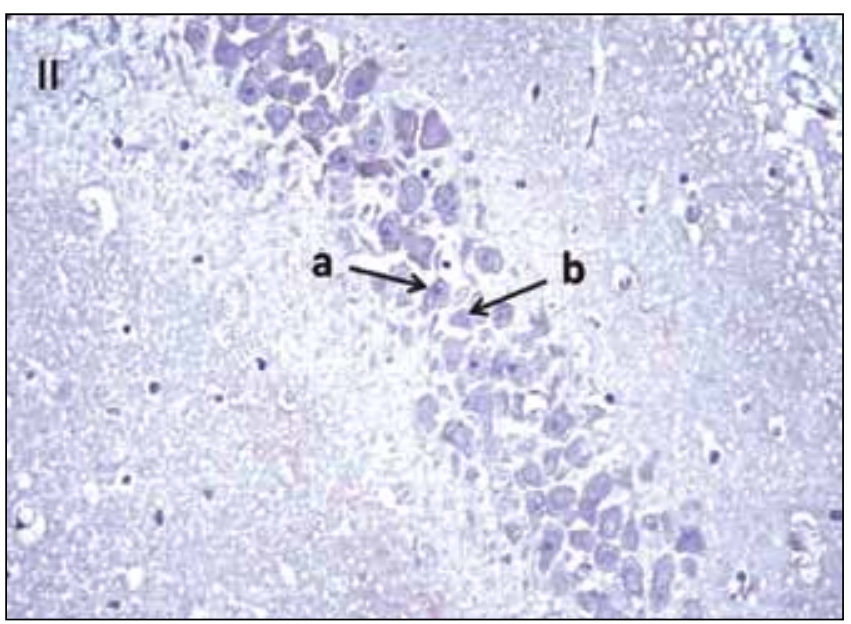

Figure 5: Photomicrographs show immunoexpression of nitric oxide synthase (NOS) immunoreactivity for each group. (X400 magnification, scale shows 100 microns). Sham operated nonhydrocephalic rat hippocampal region showed minimal NOS expression (I). At 2 weeks after hydrocephalus induction, there was a signifcant increase of NOS-positive staining cells in nontreated rats (II). Hydrocephalus induced rat pups that received 2 weeks memantine treatment also showed an increase in NOSpositive staining cells (III) but this increase was found to be significantly less as compared to non-treated rats.

a: NOS-positive staining cells

b: Cells showing no NOS expression

I: Group 1, II: Group 2, III: Group 3

a: Protected cell body and nucleus.

b: Degenerating neuron.

seemed to have affected by the hydrocephalic process but have not displayed any significant changes both in neuronal count and NOS immunoreactivity parameters in memantine treated subjects. Further comprehensive studies are needed to clarify those points in a detailed way.

In conclusion, the findings of the present study simply point out that, hippocampal neurons may constitute important targets for injury secondary to hydrocephalic process, also in the infantile hydrocephalus model Early anti-excitotoxic treatment with memantine, a non-competitive NMDA receptor antagonist, seem to reduce or attenuate the adverse effects of hydrocephalic process especially in the CA1 and CA2 subunits of the hippocampus. These results appear to support the arguments justifying the presence of the mechanism of "glutamate associated excitotoxic insult" for hippocampal injury observed in experimentally induced hydrocephalus. We believe that the applicability of anti-excitotoxic treatment in preventing neuronal injury secondary to hydrocephalic process should be set forth with future comprehensive experimental and clinical studies. 


\section{REFERENCES}

1. Bektas AO, Tugay M, Tugay S, Göcmez SS, Etus V, Utkan T: The effect of $\mathrm{N}$-methyl-D-aspartate receptor antagonist (memantine) on esophageal and gastric smooth muscle: Functional investigation in a rat hydrocephalus model. J Pediatr Surg 43:1666-1671, 2008

2. Block F, Schwarz M: Memantine reduces functional and morphological consequences induced by global ischemia in rats. Neurosci Lett 208: 41-44, 1996

3. Caner H, Atasever A, Kilinc K, Durgun P, Peker S, Özcan OE: Lipid peroxide level increase in experimental hydrocephalus. Acta Neurochir (Wien) 121:68-71, 1993

4. Chen HS, Wang YF, Rayudu PV, Edgecomb P, Neill JC, Segal MM, Lipton SA, Jensen FE: Neuroprotective concentrations of the N-methyl-D-aspartate open-channel blocker memantine are effective without cytoplasmic vacuolation following postischemic administration and do not block maze learning or long-term potentiation. Neuroscience 86:1121-1132, 1998

5. DelBigio MR, Bruni JE: Periventricular pathology in hydrocephalic rabbits before and after shunting. Acta Neuropathol 77: 186-195, 1988

6. Del Bigio MR, Bruni JE: Silicone oil-induced hydrocephalus in the rabbit. Childs Nerv Syst 7:79-84, 1991

7. DelBigio MR, Wang X, Wilson MJ: Sodium channel-blocking agents are not of benefit to rats with kaolin-induced hydrocephalus. Neurosurgery 51:460-467, 2002

8. Egawa T, Mishima K, Egashira N, Fukuzawa M, Abe K, Yae T, Iwasaki K, Fujiwara M: Impairment of spatial memory in kaolin-induced hydrocephalic rats is associated with changes in the hippocampal cholinergic and noradrenergic contents. Behav Brain Res 129: 31-39, 2002

9. Ehrlich $M$, Knolle E, Ciovica R, Böck P, Turkof E, Grabenwöger M, Cartes-Zumelzu F, Kocher A, Pockberger H, Fang WC, Wolner $\mathrm{E}$, Havel M: Memantine for prevention of spinal cord injury in a rabbit model. J Thorac Cardiovasc Surg 117:285-291, 1999

10. Eliasson MJ, Huang Z, Ferrante RJ, Sasamata M, Molliver ME, Snyder SH, Moskowitz MA: Neuronal nitric oxide synthase activation and peroxynitrite formation in ischemic stroke linked to neural damage. J Neurosci 19: 5910-5918, 1999

11. Etus V, Altug T, Belce A, Ceylan S: Green Tea Polyphenol (-)-Epigallocatechin Gallate Prevents Oxidative Damage on Periventricular White Matter of Infantile Rats with Hydrocephalus. Tohoku Journal of Experimental Medicine 200:203-209, 2003

12. Casson RJ: Possible role of excitotoxicity in the pathogenesis of glaucoma. Clin and Exp Ophthalmol 34: 54-63, 2006
13. Kamida T, Fujiki $M$, Ooba $H$, Anan M, Abe T, Kobayashi $\mathrm{H}$ : Neuroprotective effects of edaravone, a free radical scavenger, on the rat hippocampus after pilocarpine-induced status epilepticus. Seizure 18:71-75, 2009

14. Khan $\mathrm{OH}$, Enno T, DelBigio MR: Magnesium sulfate therapy is of mild benefit to young rats with kaolin-induced hydrocephalus. Pediatr Res 53:970-976, 2003

15. Kirino T: Delayed neuronal death in the gerbil hippocampus following ischemia. Brain Res 239:57-69, 1982

16. Klinge PM, Samii A, Mühlendyck A, Visnyei K, Meyer GJ, Walter GF, Silverberg GD, Brinker T: Cerebral hypoperfusion and delayed hippocampal response after induction of adult kaolin hydrocephalus. Stroke 34:193-199, 2003

17. Kriebel RM, McAllister JP 2nd: Pathology of the hippocampus in experimental feline infantile hydrocephalus. Neurol Res 22: 29-36, 2000

18. Masago A, Shimada S, Minami Y, Inoue K, Morimura H, Otori Y, Miyai A, Tohyama M, Yamada K: GLAST mRNA expression in the periventricular area of experimental hydrocephalus. Neuroreport 7: 2565-2570, 1996

19. Miyazawa T, Sato K, Obata K: A synaptic vesicle-associated protein (SVP-38) as an early indicator of delayed neuronal death. J Cereb Blood Flow Metab 15:462-466, 1995

20. Nakamura M, Araki M, Oguro K, Masuzawa T: Differential distribution of $68 \mathrm{Kd}$ and $200 \mathrm{Kd}$ neurofilament proteins in the gerbil hippocampus and their early distributional changes following transient forebrain ischemia. Exp Brain Res 89:31-39, 1992

21. Osborrne NN: Memantine reduces alterations to the mammalian retina, in situ, induced by ischemia. Vis Neurosci 16:45-52, 1999

22. Rao VLR, Dogan A, Todd KG, Bowen KK, Dempsey RJ: Neuroprotection by memantine, a non-competitive NMDA receptor antagonist after traumatic brain injury in rats. Brain Research 911: 96-100, 2001

23. Socci DJ, Bjugstad KB, Jones HC, Pattisapu JV, Arendash $\mathrm{GW}$ : Evidence that oxidative stress is associated with the pathophysiology of inherited hydrocephalus in the H-Tx rat model. Exp Neurol 155:109-117, 1999

24. Stieg PE, Sathi S, Warach S, Le DA, LiptonSA: Neuroprotection by the NMDA receptor-associated open-channel blocker memantine in a photothrombotic model of cerebral focal ischemia in neonatal rat. Eur J Pharmacol 375:115-120, 1999

25. Tsubokawa T, Katayama Y, Kawamata T: Impaired hippocampal plasticity in experimental chronic hydrocephalus. Brain Inj 2: $19-30,1988$ 